Arq. Bras. Med. Vet. Zootec., v.68, n.4, p.1077-1084, 2016

\title{
Influence of gender on carcass yield of twin lambs Blackbelly x Pelibuey at 56 days of age
}

\author{
[Influência do gênero no rendimento de carcaça em cordeiros gêmeos \\ Blackbelly $x$ Pelibuey aos 56 días de idade]
I. del C. García-Osorio ${ }^{1}$, J. Oliva-Hernández ${ }^{2 *}$, M.M. Osorio-Arce ${ }^{1}$, G. Torres-Hernández ${ }^{3}$, J. A. Hinojosa-Cuéllar ${ }^{4}$, R. González-Garduño ${ }^{5}$
${ }^{1}$ Colegio de Postgraduados - Campus Tabasco - Tabasco, México
${ }^{2}$ Campo Experimental Huimanguillo - Instituto Nacional de Investigaciones Forestales - Agrícolas y Pecuarias- Tabasco, México
${ }^{3}$ Colegio de Postgraduados - Campus Montecillo - Estado de México, México
${ }^{4}$ Universidad Popular de la Chontalpa - Tabasco, México
${ }^{5}$ Unidad Regional Universitaria Sursureste - Universidad Autónoma Chapingo - Tabasco, México

\begin{abstract}
The aim of this study was to determine the influence of gender on pre-weaning growth, yield and weight of primal cuts of the carcass of Blackbelly x Pelibuey lambs. 16 twin lambs were used. The lamb gender was the fixed factor. The variables evaluated were: body weight at birth and at weaning, average daily weight gain, weight and yield of carcass and primal cuts: neck, arm, thorax, abdomen and leg. Gender did not affect $(\mathrm{P}>0.05)$ body weight at birth. However, the pre-weaning average daily weight gain and body weight at weaning were affected $(\mathrm{P}<0.05)$ by the gender. Hot carcass yield and weight and primal cuts were not affected $(\mathrm{P}>0.05)$ by the gender of the lamb. Nevertheless, the area of the Longissimus dorsi muscle and cavity fat were different between males and females $(\mathrm{P}<0.05) 11.5 \pm 0.73 \mathrm{~cm}^{2}$ and $198 \pm 0.05 \mathrm{~g} \mathrm{vs} 9.3 \pm 0.73 \mathrm{~cm}^{2}$ and $282 \pm 0.05 \mathrm{~g}$, respectively. In conclusion, in twin lambs Blackbelly x Pelibuey males had greater average daily weight gain and body weight at weaning than females. Carcass yield and weight and primal cuts were not affected by the gender of the lamb. However, males had greater area of the L. dorsi muscle than females and these in turn had a greater amount of cavity fat than males.
\end{abstract}

Keywords: carcass composition, ewe productivity, growth, hair sheep, humid tropic

\section{RESUMO}

Objetivou-se determinar a influência do gênero no crescimento pré-desmame, no rendimento e no peso dos cortes primários de carcaça de cordeiros Blackbelly x Pelibuey. Utilizaram-se 16 cordeiros gêmeos. Os dados foram analisados em um desenho completamente ao acaso, em que o gênero dos corderos foi o fator fixo. As variáveis avaliadas foram: peso vivo ao nascimento e ao desmame, ganho diário de peso, peso e rendimento de carcaças e dos cortes primários: pescoço, braço, tórax, abdômen e perna. O gênero não afetou $(P>0,05) o$ peso vivo ao nascimento. No entanto, o ganho diário de peso e o peso vivo ao desmame foram afetados, sendo esses valores superiores nos machos $(P<0,05)$. O peso e o rendimento das carcaças quentes e dos cortes primários não foram afetados $(P>0,05)$ pelo gênero do cordeiro. Entretanto, a área do músculo Longissimus dorsi e a gordura cavitária foram diferentes entre machos e fêmeas $(P<0,05): 11.5 \pm 0.73 \mathrm{~cm}^{2}$ e $198 \pm 0.05 \mathrm{~g}$ vs. $9.3 \pm 0.73 \mathrm{~cm}^{2}$ e $282 \pm 0.05 \mathrm{~g}$, respectivamente. Em conclusão, nos cordeiros gêmeos Blackbelly $x$ Pelibuey, os machos tiveram maior ganho diário de peso e maior peso vivo ao desmame do que as fêmeas. $O$ peso e o rendimento da carcaça bem como os cortes primários não foram afetados pelo gênero do cordeiro. Todavia, os machos tiveram maior área do músculo L. dorsi que as fêmeas e estas tiveram maior quantidade de gordura cavitária que os machos.

Palabras-chave: composição carcaça, productivida de ovelhas, crescimento, ovinos de pêlo, trópicos úmidos

Recebido em 25 de fevereiro de 2015

Aceito em 24 de fevereiro de 2016

*Autor para correspondência (corresponding author)

E-mail: olivajh20@yahoo.com.mx 


\section{García-Osorio et al.}

\section{INTRODUCTION}

The high price of a balanced feed to fatten sheep and value acquired by finishing sheep (standing) has slowed the growth of sheep inventory in Mexico. These circumstances make it necessary to seek alternatives for nutritional management and marketing alternatives to improve the final price of sheep in order to obtain greater commercial benefit for producers. One option is to diversify meat products of ovine origin at an early age (young lambs) in order to reduce feeding costs in the production system and that these products gain greater economic value. However, there are several factors such as genotype, birth type, lambing weight, lambing season, gender, age of lamb at weaning and lambing number (Hinojosa-Cuellar et al., 2009, 2012; Ríos-Utrera et al., 2014) that can influence the growth of lambs and their final body composition (carcass and / or meat).

In the case of hair sheep breeds there is information documenting the influence of gender on pre-weaning growth (Ríos-Utrera et al., 2014). However, there is no information on the carcass yield and composition of these lambs at ages below 70 days. Studies on yield and body composition of hair sheep have been conducted in stages after weaning under different feeding systems (Combellas, 1997; Partida et al., 2009; Macías-Cruz et al., 2010). In addition, in studies evaluating the lamb growth the productive performance of ewes during lactation or their subsequent reproductive behavior is not documented.

Therefore, the aim of this study was to determine the influence of gender of twin lambs on preweaning growth, yield and weight of primal cuts of the carcass of lambs Blackbelly $x$ Pelibuey slaughtered at 56 days of age. Collaterally, productive and reproductive performance of ewes are described.

\section{MATERIALS AND METHODS}

The study was carried out in a sheep farm located in Huimanguillo, Tabasco, México $\left(17^{\circ}\right.$ $50^{\prime} \mathrm{N}$ and $93^{\circ} 23^{\prime} \mathrm{W}$ ), where the climate is warm and humid with rainfall throughout the year (Af) and an annual average ambient temperature of $27.8^{\circ} \mathrm{C}$ (Anuario..., 2007).
Sixteen twin lambs (females $=7$ and males $=9$ ) Blackbelly $\mathrm{x}$ Pelibuey born in summer, from eight multiparous ewes with eight lambings were used. The data were analyzed on a completely randomized design having as a fixed factor the lamb gender. Protocol was reviewed and approved by the Institutional Animal Care and Use Committee at Centro de Investigación Regional Golfo Centro, Instituto Nacional de Investigaciones Forestales, Agrícolas y Pecuarias.

Lambs remained stabled during the whole lactation stage and were fed by controlled suckling, commercially available dietary supplement (starting from five days old, 18\% $\mathrm{CP}$ ) and free access Cynodon plectostachyus and Gliricidia sepium hay (starting from 15 days old). Controlling access to suckling was applied starting from the second week of the lamb life and consisted in restricting access of lambs to suckling for six hours (8:00 to 14:00). From the third week and to conclude lactation, lambs did not have access to suckling during ten hours (08:00 to 18:00).

To calculate the pre-weaning average daily weight gain (ADWG), lambs were weighted at birth and at weaning (56 days old).

At 56 days of age, lambs were slaughtered with a previous non-dairy feed fasting of 14 hours (Martínez et al., 1987). Hot carcass weight and internal fat in the abdominal and pelvic cavities (omentum-mesenteric and peri-renal) (Martínez et al, 1987; Hernández-Espinoza et al, 2012) were recorded. Subsequently, the carcass was divided into five primal cuts (neck, arm, thorax, abdomen and leg) according to the methodology of Martínez et al. (1987).

The empty weight corresponded to the difference in $\mathrm{kg}$ between weight at slaughter and weight of digestive contents, the latter was obtained as a result of obtaining the difference between the full and empty weight of the gastrointestinal tract (rumen, reticulum, omasum, abomasum, small intestine and large intestine). The carcass yield (\%) was obtained by the equation (carcass weight/slaughter weight) $x 100$. The real yield (\%) was the ratio (carcass weight/empty weight) x 100 (Martínez et al., 1987). The area of the Longissimus dorsi muscle was measured between the $12^{\text {th }}$ and $13^{\text {th }}$ rib by a plastic gridded film in $\mathrm{cm}^{2}$ (García et al., 1998). 
The variables evaluated in lambs were: body weight at birth (BWB), body weight at weaning (BWW), ADWG, weight and yield of hot carcass and real, area of $L$. dorsi muscle, weight and yield of primal cuts (neck, arm, thorax, abdomen and leg) cavity fat, head and skin. Additionally, the weight of the liver, the empty gastrointestinal tract (EGIT) and the reticulum-rumen-omasumabomasum (RROA) section were recorded.

The ewes were maintained on grazing ( $C$. plectostachyus) and supplemented as a group with commercial feed ( $300 \mathrm{~g} / \mathrm{ewe} / \mathrm{d}, 15 \% \mathrm{CP}) 30$ days before the probable lambing date. On the first week of lactation, ewes remained stabled with their litters and were fed hay $C$. plectostachyus. On the second week of lactation, ewes came out to graze (8:00 to 14:00) and the rest of the day they were with their litters (receiving hay C. plectostachyus). From the third week until the end of the lactating stage ewes were grazing for 10 hours (8:00 to 18:00). During the entire lactation stage ewes were supplemented as a group with a commercial feed (500 g/ewe/d, 15\% CP). Grazing was carried out in pastures with $C$. plectostachyus. On average, the occupation period was three days in each pasture and 25 days off.

To calculate average daily weight gain of females during the study period the ewes were weighed at lambing and at the end of lactation. Body condition was assessed using a scale from one to five (Thompson and Meyer, 1994). The litter weight at birth and weaning were recorded. The latter value was used to calculate the production efficiency of ewes through the relationship: litter weight at weaning, kg/ewe weight at $56 \mathrm{~d}$ pospartum, $\mathrm{kg}$ (Vivanco-Makie, 2011).

Reproductive management (once all ewes ended their lactation) was applied to ewes as a group during the summer. Oestrus detection was performed twice daily (7:00 and 18:00 h) for 42 days, based on the presence of an adult Blackbelly ram. Immobilization of the female at mounting by the male was considered a sign of oestrus behavior (Jainudeen and Hafez, 1996). When an ewe in oestrus was detected, this was mated with only one ram for three times at $12 \mathrm{~h}$ intervals. During mating four adult Blackbelly rams were used and it was attempted to mate them with a similar number of ewes.

Reproductive efficiency was evaluated using the following variables: interval lambing, first oestrus detected, interval lambing conception and interval between lambings (eighth to ninth lambing).

The data were analyzed in a completely randomized design having the lamb gender as a fixed factor. Previously, the Shapiro-Wilk's test was applied to data to prove that they were distributed normally and the Bartlett's test to verify homogeneity of the variances. Data from lambs were analyzed as a mixed model, where the fixed factor was the gender of the offspring and the random factor was the mother. In BWW and $\mathrm{ADWG}$ the model included $\mathrm{BWB}$ as a covariate $(\mathrm{P}<0.05)$, while in primal cuts the model included carcass weight as a covariate $(\mathrm{P}<0.05)$. For data analysis the MIXED procedure was used $(\mathrm{SAS} \circledast$, SAS, Institute Inc., Cary, NC, USA). The least square means were compared with the predicted differences method using the t-test. The values of the least square means were considered statistically significant when $\mathrm{P}<0.05$. In ewes data, the mean \pm standard deviation was obtained $(\mathrm{SAS} \circledast$, $\mathrm{SAS}$, Institute Inc., Cary, NC, USA).

\section{RESULTS}

The twin lamb gender did not affect $(\mathrm{P}>0.05)$ BWB. However, male lambs had higher ADWG pre-weaning and $\mathrm{BWW}(\mathrm{P}<0.05)$ than females (Table 1).

Table 1. Influence of gender on pre-weaning growth of twin lambs Blackbelly x Pelibuey

\begin{tabular}{lll}
\hline Variable & Gender & \\
\hline & Male & Female \\
\cline { 2 - 3 } Body weight at birth, $\mathrm{kg}$ & $2.8 \pm 0.15$ & $2.8 \pm 0.16$ \\
Body weight at weaning $(56 \mathrm{~d}), \mathrm{kg}$ & $13.2 \pm 0.66^{\mathrm{a}}$ & $12.2 \pm 0.68^{\mathrm{b}}$ \\
Average daily weight gain, g & $186 \pm 12^{\mathrm{a}}$ & $167 \pm 12^{\mathrm{b}}$ \\
Number of observations & 9 & 7 \\
\hline
\end{tabular}

Least squares mean \pm standard error in the same row with different superscript letters are significantly different $(\mathrm{P}<0.05)$. 


\section{García-Osorio et al.}

Hot carcass weight and primal cuts as well as hot carcass yield were not affected $(\mathrm{P}>0.05)$ by the gender of the lamb (Table 2). Regarding the area of the $L$. dorsi muscle and cavity fat, both were different between both sexes $(\mathrm{P}<0.05)$. Male lambs showed higher values in area of the $L$. dorsi muscle, while females had higher amount of cavity fat in relation to male lambs (Table 2).

Male lambs showed a greater weight $(\mathrm{P}<0.05)$ of EGIT compared to females (Table 2). However, liver and RROA weights were not affected by gender $(\mathrm{P}>0.05)$.

The yields of carcass primal cuts, were not affected $(\mathrm{P}>0.05)$ by the gender of the lamb. The means \pm standard deviation were: neck $7.1 \pm 1.5 \%$, arm $18.7 \pm 1.3 \%$, thorax $26.1 \pm 2.1 \%$, abdomen $22.3 \pm 1.6 \%$ and leg $24.5 \pm 1.5 \%$.

The productive and reproductive efficiency of ewes after their eighth lambing is shown in Tab. 3.

Table 2. Influence of gender on the body composition at weaning of twin lambs Blackbelly x Pelibuey

\begin{tabular}{|c|c|c|}
\hline Variable & \multicolumn{2}{|l|}{ Gender } \\
\hline & Male & Female \\
\hline Age at slaughter, d & 56 & 56 \\
\hline Empty body weight ${ }^{1}, \mathrm{~kg}$ & $11.6 \pm 0.61$ & $10.9 \pm 0.66$ \\
\hline Carcass weight, $\mathrm{kg}$ & $6.0 \pm 0.33$ & $5.7 \pm 0.36$ \\
\hline Carcass yield ${ }^{2}, \%$ & $46.2 \pm 0.51$ & $46.7 \pm 0.58$ \\
\hline Carcass real yield ${ }^{3}, \%$ & $52.5 \pm 0.45$ & $52.4 \pm 0.51$ \\
\hline Neck, kg & $0.44 \pm 0.04$ & $0.39 \pm 0.04$ \\
\hline $\mathrm{Arm}^{4}, \mathrm{~kg}$ & $1.14 \pm 0.03$ & $1.07 \pm 0.03$ \\
\hline $\mathrm{Leg}^{4}, \mathrm{~kg}$ & $1.45 \pm 0.03$ & $1.44 \pm 0.04$ \\
\hline Thorax, kg & $1.55 \pm 0.05$ & $1.53 \pm 0.05$ \\
\hline Abdomen, $\mathrm{kg}$ & $1.33 \pm 0.04$ & $1.31 \pm 0.04$ \\
\hline Area of Longissimus dorsi muscle, $\mathrm{cm}^{2}$ & $11.5 \pm 0.73^{\mathrm{a}}$ & $9.3 \pm 0.73^{\mathrm{b}}$ \\
\hline Cavity fat, $g$ & $198 \pm 0.05^{\mathrm{a}}$ & $282 \pm 0.05^{\mathrm{b}}$ \\
\hline Head, $\mathrm{kg}$ & $0.64 \pm 0.03$ & $0.59 \pm 0.03$ \\
\hline Skin, kg & $1.3 \pm 0.11$ & $1.3 \pm 0.12$ \\
\hline Liver, $g$ & $265 \pm 18$ & $225 \pm 20$ \\
\hline EGIT, $\mathrm{g}$ & $1196 \pm 55^{\mathrm{a}}$ & $999 \pm 63^{b}$ \\
\hline RROA, g & $432 \pm 31$ & $404 \pm 31$ \\
\hline Number of observations & 9 & 7 \\
\hline
\end{tabular}

1, empty body weight: body weight at slaughter-weight of digestive contents; 2, carcass yield: (carcass weight/body weight at slaughter) x100; 3, carcass real yield: (carcass weight/empty body weight) x 100; 4, refers to the weight of the two arms or legs; EGIT: empty gastrointestinal tract; RROA: reticulum-rumen-omasum- abomasum; ${ }^{\mathrm{a}, \mathrm{b}}$ Least squares mean \pm standard error in the same row with different superscript letters are significantly different $(\mathrm{P}<0.05)$.

Table 3. Changes in body weight and body condition (mean \pm standard deviation) in lactating multiparous Blackbelly x Pelibuey ewes

\begin{tabular}{ll}
\hline Variable & \\
\hline Weight at lambing, kg & $41.5 \pm 4.7$ \\
Weight at 56 d pospartum & $38.8 \pm 3.9$ \\
Average daily weight gain, g & $-48 \pm 40$ \\
Body condition at lambing & $3.1 \pm 0.7$ \\
Body condition at 56 d pospartum & $2.5 \pm 0.8$ \\
Body condition change & $-0.56 \pm 0.7$ \\
Litter weight at birth, kg & $5.57 \pm 0.6$ \\
Litter weight at weaning, kg & $25.51 \pm 0.7$ \\
Productivity 1 & $0.66 \pm 0.09$ \\
Interval lambing first oestrus, d & $86.6 \pm 16.3$ \\
Interval lambing conception, d & $89.4 \pm 16.9$ \\
Interval between lambings, ${ }^{2}$ & $240.9 \pm 17.2$ \\
Number of observations & 8 \\
\hline 1, productivity: litter weight at weaning (56 d), kg/body weight of the ewe at 56 d pospartum, kg; 2, eighth to ninth \\
lambing.
\end{tabular}




\section{DISCUSSION}

Information to study the influence of the twin lamb gender of hair breed on BWB was not found. Notwithstanding, the results of this study are consistent with those reported by GonzálezGarduño et al. (2010) and Hinojosa-Cuéllar et al. (2012) who indicate that in Pelibuey lambs the gender of the lamb does not influence birth weight. However, there are studies about hair sheep (González et al., 2002; Ríos-Utrera et al., 2014) indicating that the superiority of male lambs in BWB compared to females, is found between 3.7 and $8.5 \%$.

The superiority of male lambs in ADWG preweaning and BWW compared to females is consistent with that indicated by Ríos-Utrera et al. (2014) in lambs of six racial groups, with an adjusted weaning at 90 days, fed with maternal milk and a supplement $(18 \% \mathrm{CP})$, where male lambs showed a higher ADWG and BWW $(98 \pm 4$ $\mathrm{g}$ and $11.7 \pm 0.4 \mathrm{~kg}$, respectively) than that of females ( $94 \pm 4 \mathrm{~g}$ and $11.1 \pm 0.4 \mathrm{~kg}$, respectively). This effect of gender on ADWG and BWW has also been reported in Blackbelly (González et al., 2002) and Pelibuey lambs (Macedo and Arredondo, 2008).

Male and female lambs had similar weight and hot carcass yield. In this regard, Peña et al. (2005) report that in Segureña breed lamb (average age of 79 days) gender did not influence the weight and hot carcass yield which agrees with the results obtained in this research. However, hot carcass weights, carcass yield, and real yield reported by these authors for males and females was higher $(10.5 \pm 0.1 \mathrm{~kg}, 48.8 \pm 0.3 \%$ and $54.5 \pm 0.3 \%$ in males and $10.4 \pm 0.1 \mathrm{~kg}, 49.0 \pm 0.3$ and $55.1 \pm 0.3 \%$ in females, respectively) than those obtained in this study (Table 2). Meanwhile, Combellas (1997) indicates that in West-African lambs (71 days of age) there is a hot carcass weight of $7.8 \mathrm{~kg}$, a carcass yield of $50.5 \%$ and a real yield of $56.8 \%$, values that are also higher than those recorded in the present study. Differences in carcass weight and carcass yield between studies are explained, in part, by the slaughter age, racial group and feed regime to which the lambs were subjected.

The area of the L. dorsi muscle was greater in male lambs than females. In contrast to the results of this study, Macías-Cruz et al. (2010) when evaluating carcasses of lambs (average age 233 days) from three racial groups found no influence of lamb gender on $L$. dorsi muscle reporting values of $15.9 \pm 0.7$ and $17.0 \pm 0.7 \mathrm{~cm}^{2}$ for females and males, respectively. Moreover, in lambs (79 days old) of the Segureña (Peña et al., 2005) and Suffolk Down breed (between 23 and 30 days of age) (Pérez et al., 2002) it has been reported that the area of the $L$. dorsi muscle is not affected by lamb gender.

The values obtained for the cavity fat contrast with the results of Partida et al. (2009) who indicate that in genotypes Pelibuey, Pelibuey $\mathrm{x}$ Suffolk and Pelibuey $\mathrm{x}$ Dorset deposits of omental and mesenteric fat showed no significant differences between females and males. However, a tendency to be higher in females was observed.

The EGIT was greater in male lambs than females. However, it is still necessary to determine whether a heavier weight of the gastrointestinal tract shows a relationship with increased absorption surface and/or rumen function that will improve the ability to digest and convert ingested food into muscle tissue.

The yields of carcass primal cuts were not affected by the gender of the lamb. In a similar manner to these results, Pérez et al. (2002) indicate that in Suffolk Down lambs gender did not influence the yield of primal cuts. However, in lambs of the Segureña breed it has been reported that gender influences the neck and shoulder yield being greater in males (Peña et al., 2005). Macías-Cruz et al. (2010) reported that gender affected rib and shoulder yield. Males had a higher shoulder yield and females had a higher rib yield. Information of these two authors differs from the results obtained in the present study. Differences are probably attributed to genotypes, age and feeding system of evaluated lambs.

Weights of studied ewes are found within the body weight variation reported in adult Pelibuey (31.7 \pm 3.7$)$ (Martínez et al., 1987) and Blackbelly $(35.0 \pm 6.5 \mathrm{~kg})$ ewes (Dzib et al., 2011). During lactation ewes had a negative ADWG, which was reflected in body condition and body weight at the end of lactation. The negative ADWG and reduction in body condition of the ewes indicate that the feeding system used did not meet the nutrient requirements to support lactation of 
lambs. In agreement with the above result, Morales-Terán et al. (2004) and Pérez et al. (2009) show that Pelibuey multiparous ewes (whose litters had access to continuous suckling) had a negative weight change during the first 56 days of lactation in the order of $1.9 \mathrm{~kg}$ (MoralesTerán et al., 2004) and 2.5kg (Pérez et al., 2009). While Espinoza et al. (1998) indicate that when offering the Pelibuey multiparous ewes (suckling a single lamb) $5.2 \mathrm{Mcal} \mathrm{EM} / \mathrm{ewe} / \mathrm{d}$ a positive weight change $(0.5$ to $2.7 \mathrm{~kg})$ is achieved during the first 60 days of lactation.

As to the litter weight, Cadenas-Cruz et al. (2012) report the hybrid litters (Pelibuey $x$ Blackbelly) from Blackbelly ewes in their eighth lambing weight at birth $4.0 \pm 0.2 \mathrm{~kg}$ and at weaning (fitted at 90 days of age) $14.3 \pm 0.6$, while in the case of litters with two lambs, Rastogi (2001) reports that in the Blackbelly breed these weight $17.6 \mathrm{~kg}$ at 56 days of age and Magaña-Monforte et al. (2013) state that in the Pelibuey breed the litter weight at weaning (fitted at 60 days) with two lambs is $22.0 \mathrm{~kg}$, values which are lower to those found in the present study. The pre-weaning ADWG of lambs and litter weight at weaning recorded in the present study suggest that allowing lambs free access to a food supplement plus $C$. plectostachyus and $G$. sepium hay during the control period of lactation does not affect productive performance.

Of the eight ewes studied only one ewe repeated estrous behavior. However, all the ewes had a subsequent lambing (ninth lambing). In Pelibuey multiparous ewes that suckle their offspring ad libitum the first ovulation and the proportion of ewes showing ovulation is variable. Pérez et al. (2009) indicate that the first ovulation occurs on average at 52.6 days postpartum in $18.8 \%$ of the ewes; while Morales-Terán et al. (2004) point out that the first ovulation occurs at 60.5 days postpartum in $70 \%$ of the ewes. Furthermore, Cadenas-Cruz et al. (2012) reported that in Blackbelly ewes suckling continuously their litter and that were exposed to the continuous presence of rams for mating during the postpartum period, $72.4 \%$ achieve conception within 90 days and $84.1 \%$ before 120 days postpartum. In the present study, ewes were exposed to rams at $75 \pm 15.9$ days postpartum and achieved conception at $89 \pm 16.9$ days postpartum which agrees with that reported for Blackbelly ewes (Cadenas-Cruz et al., 2012).

Moreover, ewes showed an interval between lambings within the limits (230 and 260 days) reported on commercial sheep farms in the tropical region of Mexico (Galina et al., 1996; Hinojosa-Cuéllar et al., 2015; Magaña-Monforte et al., 2013). Additionally, the detected interval value between lambings was similar to that indicated (240 days) as optimal to achieve three lambings in a period of two years (MagañaMonforte et al., 2013).

\section{CONCLUSIONS}

Pre-weaning growth in twin Blackbelly $x$ Pelibuey lambs is influenced by gender. Male lambs show superiority in their average daily weight gain, body weight at weaning and area of Longissimus dorsi muscle compared to females. Carcass weight and yield as well as primal cuts are not affected by lamb gender. Moreover, the feed system and management of the lactation used in multiparous Blackbelly x Pelibuey ewes caused that these showed a change of negative weight and a reduction of their body condition. However, they managed to be efficient productively and reproductively.

\section{ACKNOWLEDGMENTS}

The authors thank to Consejo Nacional de Ciencia y Tecnología (CONACYT) for the scholarship granted to the first author to study a Master Degree in the program "Producción Agroalimentaria en el Trópico" of the Colegio de Postgraduados Campus Tabasco.

\section{REFERENCES}

ANUARIO ESTADÍSTICO TABASCO. Tabasco: INEGI, 2007. 574p.

CADENAS-CRUZ，P.J.; OLIVA-HERNÁNDEZ，J.; HINOJOSA-CUÉLLAR, J.A. Productivity of Blackbelly ewes and their hybrid litter under grazing. J. Anim. Vet. Adv., v.11, p.97-102, 2012.

COMBELLAS, J.B. DE. Calidad de la canal en ovejas west-African y sus cruces. In: GONZÁLEZ-STAGNARO, C. (Comp.). Ovinos de pelo: ovis tratado de patología y producción ovina. Madrid: Luzán 5 S.A, 1977. p.75-82. 
DZIB, C.A.; ORTIZ DE MONTELLANO, A.; TORRES-HERNÁNDEZ, G. Variabilidad morfoestructural de ovinos Blackbelly en Campeche, México. Arch. Zootec., v.232, p.1291-1301, 2011.

ESPINOZA， J.L.; LÓPEZ-MOLINA， O.; RAMÍREZ-GODÍNEZ， J.A.; JIMÉNEZ， J.; FLORES, A. Milk composition, postpartum reproductive activity and growth of lambs in Pelibuey ewes fed calcium soaps of long chain fatty acids. Small Ruminant Res., v.27, p.119124, 1998.

GALINA, M.A.; MORALES, R.; SILVA, E.; LÓPEZ, B. Reproductive performance of Pelibuey and Blackbelly sheep under tropical management systems in Mexico. Small Ruminant Res., v.22, p.31-37, 1996.

GARCÍA, J.A.; NUÑEZ, F.A.; RODRÍGUEZ, F.A. et al. Calidad de la canal y de la carne de borregos Pelibuey castrados. Тéc. Ресu. Мéx., v.36, p.225-232, 1998.

GONZÁLEZ, R.; TORRES, G.; CASTILLO, M. Crecimiento de corderos Blackbelly entre el nacimiento y el peso final en el trópico húmedo de México. Vet. Méx., v.33, p.443-453, 2002.

GONZÁLEZ-GARDUÑO, R.; TORRESHERNÁNDEZ， G.; ARECE-GARCÍA， J. Comportamiento productivo y reproductivo de ovinos Pelibuey en un sistema de pariciones aceleradas con tres épocas de empadre al año. Zootec. Trop., v.28, p.51-56, 2010.

HERNÁNDEZ-ESPINOZA， D.F.; OLIVAHERNÁNDEZ, J.; PASCUAL-CÓRDOVA, A.; HINOJOSA-CUÉLLAR, J.A. Descripción de medidas corporales y composición de la canal en corderas Pelibuey: estudio preliminar. Rev. Cient. FCV-LUZ, v.22, p.24-31, 2012.

HINOJOSA-CUÉLLAR, J.A.; OLIVAHERNÁNDEZ, J.; TORRES-HERNÁNDEZ, G. et al. Factores que afectan el crecimiento predestete de corderos Pelibuey en el trópico húmedo de México. Univ. Cienc., v.28, p.163171, 2012.

HINOJOSA-CUÉLLAR, J.A.; OLIVAHERNÁNDEZ, J.; TORRES-HERNÁNDEZ, G. et al. Productividad de ovejas $\mathrm{F}_{1}$ Pelibuey $\mathrm{x}$ Blackbelly y sus cruces con Dorper y Katahdin en un sistema de producción del trópico húmedo de Tabasco, México. Arch. Med. Vet., v.47, p.167-174, 2015.
HINOJOSA-CUÉLLAR, J.A.; REGALADOARRÁZOLA, F.M.; OLIVA-HERNÁNDEZ, J. Crecimiento prenatal y predestete en corderos Pelibuey, Dorper, Katahdin y sus cruces en el sureste de México. Rev. Cient. FCV-LUZ, v.19, p.522-532, 2009.

JAINUDEEN, M.R.; HAFEZ, E.S.E. Ovejas y cabras. In: HAFEZ, E.S.E. (Ed.). Reproducción e inseminación artificial en animales. México: McGraw-Hill Interamericana, 1996. p.311-322.

MACEDO, R.; ARREDONDO, V. Efecto del sexo, tipo de nacimiento y lactancia sobre el crecimiento de ovinos Pelibuey en manejo intensivo. Arch. Zootec., v.57, p.219-228, 2008.

MACÍAS-CRUZ, U.; ÁLVAREZ-VALENZUELA, F.D.; RODRÍGUEZ-GARCÍA, J. et al. Crecimiento y características de canal en corderos Pelibuey puros y cruzados F1 con razas Dorper y Katahdin en confinamiento. Arch. Med. Vet., v.42, p.147154, 2010.

MAGAÑA-MONFORTE, J.G.; HUCHIN-CAB, M.; AKE-LÓPEZ, R.J.; SEGURA-CORREA, J.C. A field study of reproductive performance and productivity of Pelibuey ewes in southeastern Mexico. Trop. Anim. Health Prod., v.45, p.1771-1776, 2013.

MARTÍNEZ, A.M.M.; BORES, R.F.; CASTELLANOS, A.F. Zoometría y predicción de la composición corporal de la borrega Pelibuey. Те́c. Ресu. Ме́x., v.25, p.72-84, 1987.

MORALES-TERÁN, G.; PRO-MARTÍNEZ, A.; FIGUEROA-SANDOVAL, B. et al. Amamantamiento continuo o restringido y su relación con la duración del anestro postparto en ovejas Pelibuey. Agrociencia, v.38, p.165-171, 2004.

PARTIDA, J.A.; BRAÑA, D.; MARTÍNEZ, L. Desempeño productivo y propiedades de la canal de ovinos Pelibuey y sus cruzas con Suffolk o Dorset. Тéc. Ресu. Мéx., v.47, p.313-322, 2009.

PEÑA, F.; CANO, T.; DOMENECH, V. et al. Influence of sex, slaughter weight and carcass weight on "non-carcass" and carcass quality in segureña lambs. Small Ruminant Res., v.60, p.247-254, 2005. 
PÉREZ, P.; HERNÁNDEZ, V.M.; FIGUEROA, B. et al. Efecto del tipo de amamantamiento en la actividad ovárica postparto de ovejas Pelibuey y tasas de crecimiento de corderos en los primeros 90 días de edad. Rev. Cient. FCV-LUZ, v.19, p.343-349, 2009.

PÉREZ, P.; MAINO, M.; TOMIC, G. et al. Carcass characteristics and meat quality of Suffolk down suckling lambs. Small Ruminant Res., v.44, p.233-240, 2002.

RASTOGI, R.K. Production performance of barbados Blackbelly sheep in Tobago, west Indies. Small Ruminant Res., v.41, p.171-175, 2001.
RÍOS-UTRERA, A.; CALDERÓN-ROBLES, R.; LAGUNES-LAGUNES, J.; OLIVAHERNÁNDEZ, J. Ganancia de peso predestete en corderos Pelibuey y sus cruces con Blackbelly, Dorper y Katahdin. Nova Sci., v.6, p.272-286, 2014.

THOMPSON, J.; MEYER, H. Body condition scoring of sheep. Oregon: OSU, 1994. [4p].

VIVANCO-MACKIE, H.W. Uso de tecnologías reproductivas avanzadas en programas de mejora genética en ovinos. In: GÓNZALEZ, R.; BERÚMEN, A.; MONTES DE OCA, R. (Comp.). Tópicos selectos en producción ovina. Carretera, México: Universidad Autónoma Chapingo, 2011. p.79-94. 